\title{
Temporal Bone
}

National Cancer Institute

\section{Source}

National Cancer Institute. Temporal Bone. NCI Thesaurus. Code C12797.

A large irregular bone situated at the base and side of the skull, connected with the mandible via the temporomandibular joint. The temporal bone consists of the squamous, tympanic and petrous parts. The petrous portion of the temporal bone contains the vestibulocochlear organ of the inner ear. 